\title{
DNA methylation study of fetus genome through a genome-wide analysis
}

Hong-Dan Wang ${ }^{1,2+}$, Qiao-Fang Hou ${ }^{1 \dagger}$, Qian-Nan Guo ${ }^{1}$, Tao Li', Dong Wu', Xian-Ping Zhang ${ }^{3}$, Yan Chu', Miao He ${ }^{1}$, Hai Xiao', Liang-Jie Guo ${ }^{1}$, Ke Yang ${ }^{1}$, Shi-Xiu Liao ${ }^{1 *}$ and Bo-Feng Zhu ${ }^{2^{*}}$

\begin{abstract}
Background: DNA methylation is a crucial epigenetic modification of the genome which is involved in embryonic development, transcription, chromatin structure, $\mathrm{X}$ chromosome inactivation, genomic imprinting and chromosome stability. Consistent with these important roles, DNA methylation has been demonstrated to be required for vertebrate early embryogenesis and essential for regulating temporal and spatial expression of genes controlling cell fate and differentiation. Further studies have shown that abnormal DNA methylation is associated with human diseases including the embryonic development diseases. We attempt to study the DNA methylation status of CpG islands in fetus related to fetus growth and development.
\end{abstract}

Methods: GeneChip ${ }^{\circledR}$ Human Tiling 2.0R Array set is used for analysis of methylated DNA in a whole-genome wide in 8 pairs amniotic fluid and maternal blood DNA samples.

Results: We found 1 fetus hypermethylation DNA markers and 4 fetus hypomethylation DNA markers though a Genome-wide analysis. These DNA markers all found to be associated with the critical genes for fetus growth and development (SH2D3C gene, EML3 gene, TRIM71 gene, HOXA3 gene and HOXA5 gene).

Conclusions: These genes can be used as a biomarker for association studying of embryonic development, pathological pregnancy and so on. The present study has provided new and fundamental insights into the roles that DNA methylation has in embryonic development and in the pathological pregnancy.

Keywords: DNA methylation, Fetus, GeneChip ${ }^{\circledR}$ human tiling 2.0R array set, Clone sequencing, Embryonic development

\section{Background}

DNA methylation, the most important and common part of epigenetic, regulates gene expression by modified DNA without the changing of the genomic sequence. DNA methylation is a process in which a methyl group is covalently bound to a 5-position of cytosine in the context of a cytosine-guanine dinucleotide $(\mathrm{CpG})$ in the mammalian genome [1]. Methylation of CpG-rich promoters is used by mammals to prevent transcriptional initiation, to ensure the inactivation of $\mathrm{X}$ chromosome and the silence of imprinted genes and parasitic DNAs.

\footnotetext{
*Correspondence: syyliaoshixiu@163.com; zhubofeng7372@126.com ${ }^{\dagger}$ Equal contributors

'Medical Genetic Institute of Henan Province, Henan Provincial People's Hospital, People's Hospital of Zhengzhou University, Zhengzhou 450003, PR China

${ }^{2}$ School of Medicine, Xi'an Jiaotong University, Xi'an 710061, PR China Full list of author information is available at the end of the article
}

Recent studies show that methylation also affects the stability and structure of chromosomes. And the abnormal hypomethylation can cause many human diseases including many kinds of cancer $[2,3]$. However, the potential roles of methylation in tissue-specific gene expression and in the regulation of CpG-poor promoters are less well established [4]. On the other hand, Xiang $\mathrm{H}$ et al. estimate that more than $0.11 \%$ of genomic cytosines are methylcytosines, all of which probably occur in CG dinucleotides. CG methylation is substantially enriched in gene bodies and positively correlated with gene expression levels, suggesting it has a positive role in gene transcription [5].

Recently, researchers have conducted extensive research on the mechanism of DNA methylation and its role in embryonic development. DNA methylation has been demonstrated to be required for vertebrate early 
embryogenesis and can regulate temporal and spatial expression of genes controlling cell fate and differentiation which is a complicated and predetermined developmental program. Moreover, DNA methylation provides necessary direction for the multitude of changes that are required to proceed from a fertilized oocyte to a fully developed adult animal [6,7]. Sperm and eggs carry distinctive epigenetic modifications that are adjusted by reprogramming after fertilization. The paternal genome in a zygote undergoes active DNA demethylation before the first mitosis [8]. During the early phases of mammalian development, DNA methylation is extensively reprogrammed [9]. The maintenance of DNA methylation and normal methylation level is necessary for normal embryonic development and tissue-specific differentiation. The changes of DNA methylation will result in abnormal expression of gene and produce various phenotypes such as pregnancy failure, congenital defects and acquired diseases. For the design of targeted therapies to abnormal DNA methylation, there is important theoretical and clinical significance to studying and understanding the status of DNA methylation in the development of embryo.

Methylated Microarray analysis is efficient technology platform for looking for epigenetic methylation markers. With the completion of many whole-genome sequences, new types of genome-wide experiments are possible. Tiling Arrays offer a physical readout of a genome and can be used as a discovery tool for mapping sites of DNA interaction in chromatin immunoprecipitation (ChIP) experiments, understanding global epigenomic changes like methylation. Currently, most studies use various animal models to study the methylation status during embryonic development. In this study, GeneChip ${ }^{\circ u}$ man Tiling 2.0R Array set is used to look for methylation markers in amniotic fluid samples in an early development of human embryo. Moreover, clone sequencing is used to test and verify the results of Methylated Microarray analysis. And Real-time quantitative PCR (RTQ-PCR) is used to verify the function of hypermethylation and hypomethylation in the identified genomic regions.

\section{Methods}

\section{Study samples}

Eight women with 18-24 weeks of euploid pregnancies admitted to Prenatal Diagnosis Center of Henan Provincial People' hospital between March 2013 and May 2013 were recruited. $10 \mathrm{ml}$ maternal peripheral blood and $20 \mathrm{ml}$ amniotic fluid were collected from the 8 participants. All samples were frozen at $-80^{\circ} \mathrm{C}$ before analysis. The pregnant information about the participants was shown in Table 1. All the participants were not complicated with any diseases and provided their written
Table 1 General information about the participants

\begin{tabular}{ccccc}
\hline Sample ID & $\begin{array}{c}\text { Maternal } \\
\text { age (years) }\end{array}$ & $\begin{array}{c}\text { Reproductive } \\
\text { history }\end{array}$ & $\begin{array}{c}\text { Pregnant } \\
\text { week }\end{array}$ & $\begin{array}{c}\text { Fetal } \\
\text { sex }\end{array}$ \\
\hline p356 & 28 & G1P0 & 18 week & $46, X X$ \\
p357 & 37 & G2P0 & 19 week + 3 day & $46, X X$ \\
p358 & 33 & G1P0 & 20 week & $46, X X$ \\
p359 & 24 & G3P0 & 19 week + 6 day & $46, X Y$ \\
p360 & 32 & G4P1 & 22 week & $46, X Y$ \\
p362 & 27 & G1P0 & 21 week + 5 day & $46, X X$ \\
p363 & 38 & G3P1 & 20 week + 5 day & $46, X X$ \\
p364 & 30 & G2P1 & 24 week + 2 day & $46, X X$ \\
\hline
\end{tabular}

informed consent for the collection of the samples and subsequent analysis. The investigation was conducted in accordance with humane and ethical research principles of Henan Provincial People' hospital, China. This study was approved by the Ethics Committee of Henan Provincial People's Hospital, China.

\section{Exclusion of maternal DNA}

The fifteen autosomal STR loci and a Amelogenin locus are amplified to determine whether there is maternal DNA in fetus amniotic fluid by using the PowerPlex ${ }^{\circ} 16$ system kit in a multiplex amplification reaction system following manufacturer's instructions using $25 \mu \mathrm{l}$ reactions containing $1.0 \mu \mathrm{l}(0.5-2 \mathrm{ng})$ genomic DNA, $5.0 \mu \mathrm{l}$ PowerPlex $^{\circ} 165 \times$ Master Mix, $5.0 \mu$ l PowerPlex $165 \times$ Primer

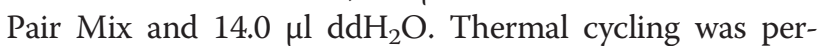
formed using the GeneAmp ${ }^{\circ}$ PCR System 9700 (Applied Biosystems, Foster City, CA, USA). Temperature cycling conditions for PCR reactions are as follows: denaturation for $11 \mathrm{~min}$ at $95^{\circ} \mathrm{C}$, and then $1 \mathrm{~min}$ at $96^{\circ} \mathrm{C}$, followed by 10 cycles for $30 \mathrm{~s}$ at $94^{\circ} \mathrm{C}, 30 \mathrm{~s}$ at $60^{\circ} \mathrm{C}, 45 \mathrm{~s}$ at $70^{\circ} \mathrm{C}$, then 20 cycles for $30 \mathrm{~s}$ at $90^{\circ} \mathrm{C}, 30 \mathrm{~s}$ at $60^{\circ} \mathrm{C}, 45 \mathrm{~s}$ at $70^{\circ} \mathrm{C}$ and a final elongation step at $60^{\circ} \mathrm{C}$ for $30 \mathrm{~min}$.

The PCR products have been separated and detected by capillary electrophoresis on an ABI 3130 Genetic Analyzer (Applied Biosystems, Foster City, CA, USA). $2 \mu \mathrm{l}$ PCR product or Allelic Ladder has been mixed with $15 \mu \mathrm{l} \mathrm{Hi}$-Di formamide and $0.5 \mu \mathrm{L}$ internal lane standard ILS 600 (Promega, WI, USA). The loading mixture has been denatured at $95^{\circ} \mathrm{C}$ for $3 \mathrm{~min}$, followed by chilling on ice for $3 \mathrm{~min}$ immediately. STR alleles have been analyzed by comparison with kit allelic ladders using the GeneMapper ID 3.2 software (Applied Biosystems, Foster City, CA, USA). Control DNA from cell line 9947A (Promega, Madison, WI, USA) has been genotyped as standard reference in all experiments.

\section{Methylated DNA capture}

Methylamp $^{\text {TM }}$ Methylated DNA Capture kit (Epigentek Group Incorporation, Farmingdale, New York, USA) has 
been used to enrich and capture methylated DNA fragments from blood and amniotic fluid samples for use in gene-specific DNA methylation studies on a genome wide scale. According to the manufacturer's protocol of the kit, Methylated DNA Capture include the following steps: i) DNA isolation, ii) breaking DNA as fragments by sonicator: sonication for $10 \mathrm{~s}$, and pause $30 \mathrm{~s}$, repeat it 15 times at $100 \mathrm{~W}$, check the DNA size by running $1.2 \%$ agarose gel, iii) incubating sonicated/digested DNA at $98^{\circ} \mathrm{C}$ for $3 \mathrm{~min}$ and immediately put on ice, iv) bisulfite conversion and methylated DNA immunoprecipitation, v) release of mDNA from antibody complex, vi) capturing of mDNA, vii) elution of mDNA. Following methylated DNA immunoprecipitation (meDIP) processed, the methlation of the DNA can be analyzed using meDIP-ChIP.

\section{DNA methylation analysis}

GeneChip Human Tiling 2.0R Array set (Affymetrix Incorporation, Santa Clara, CA, USA) has been used for analysis of methylated DNA in a whole-genome wide. GeneChip Fluidics Station 400 and GeneChip Scanner 3000 7G (Affymetrix Incorporation, Santa Clara, CA, USA) are needed for analysis. According to the Affymetrix chip-on-chip procedures we first amplified immunoprecipitated DNA targets using the following cycle conditions: 14 cycles for $30 \mathrm{~s}$ at $95^{\circ} \mathrm{C}, 30 \mathrm{~s}$ at $45^{\circ} \mathrm{C}, 30 \mathrm{~s}$ at $55^{\circ} \mathrm{C}, 1 \mathrm{~min}$ at $72^{\circ} \mathrm{C}$, then 14 cycles for $30 \mathrm{~s}$ at $95^{\circ} \mathrm{C}$, $30 \mathrm{~s}$ at $45^{\circ} \mathrm{C}, 30 \mathrm{~s}$ at $55^{\circ} \mathrm{C}$ (for every subsequent cycle add 5 second), $1 \mathrm{~min}$ at $72^{\circ} \mathrm{C}$, and $4^{\circ} \mathrm{C}$ for ever. Secondly, we purified the PCR products using MiniElute PCR purification kit (Qiagen Incorporation, Valencia, $\mathrm{CA}$, Spain) and got fragmentation mix, then put up fragmentation mix for Tiling array, following this step we used GeneChip WT Double-Stranded DNA Terminal Labeling Kit (Affymetrix Incorporation, Santa Clara, CA, USA) to label fragmented Double-Stranded DNA, and used GeneChip Hybridization, Wash, and Stain Kit (Affymetrix Incorporation, Santa Clara, CA, USA) to hybridize, wash and stain the labeled target DNA according to the procedure of the kit. Finally, we scan the barcode on the chip using appropriate protocol.

\section{Clone sequencing}

Clone sequencing strategy has been used to verify the selected methylation markers by microarray analysis method in a whole-genome wide (Sangon Biotech Incorporation, Shanghai, China). Before the clone sequencing was conducted, bisulfite conversion of the sample genomic DNA was done by using EpiTect Bisulfite kit (Qiagen Incorporation, Valencia, CA, Spain) according to the manufacturer's procedure. Nine fetus hypermethylation markers and twelve fetus hypomethylation markers were tested. The primer sequences were shown in Table 2.

\section{Real-time quantitative PCR}

Real-time quantitative PCR was used to verify the function of hypermethylation and hypomethylation in the identified genomic regions. Total RNA was prepared from maternal peripheral blood and amniotic fluid samples (400 mg) using TRIzol ${ }^{\circ}$ Reagent (Life Technologies Incorporation, CA, USA). Reverse transcription was carried out with the GeneAmp PCR System 9700 (Applied Biosystems, Foster City, CA, USA) in a reaction volume of $20 \mu \mathrm{l}$ containing $5 \mu \mathrm{l}$ of total RNA, $1 \mu \mathrm{l}$ random Primers, $5 \mu \mathrm{l}$ Rnase-free $\mathrm{ddH}_{2} \mathrm{O}, 4 \mu \mathrm{l}$ Reaction Buffer $5 \times$, $2 \mu \mathrm{L}$ dNTP $\operatorname{Mix}(10 \mathrm{mmol} / \mathrm{L}), 20 \mathrm{U}$ ribonuclease inhibitor (Applied Biosystems, Foster City, CA, USA), and $20 \mathrm{U}$ of reverse transcriptase (Life Technologies Incorporation, Ambion. CA, USA). Specific primers used to amplify the genes ERG, SH2D3C, EML3, TRIM71, HOXA3, HOXA11, and HOXA5 (showed in Table 3) were designed using online software Primer 3 Version 0.4.0 (Whitehead Institute, USA), and the endogenous $\beta$-actin was employed as an internal standard. Sybr Green RTQ-PCR analysis were performed with LightCycler480 Software Setup (Roche Incorporation, Basel, Switzerland). RTQ-PCR was performed using the following cycle parameters: 3 minutes at $95^{\circ} \mathrm{C}$, followed by 40 cycles of $15 \mathrm{sec}$ at $95^{\circ} \mathrm{C}$ and $40 \mathrm{~s}$ at $60^{\circ} \mathrm{C}$. For each gene, RTQ-PCR was conducted in $20 \mu \mathrm{l}$ reactions of $1 \mu \mathrm{l}$ cDNA ( $5 \mathrm{ng}$ ), $10 \mu \mathrm{l}$ Sybr Green qPCR Master Mix 2× (Applied Biosystems, Foster City, CA, USA),

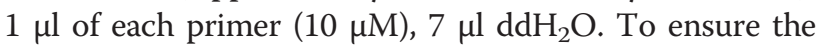
quality of the measurements, both negative and positive controls were systematically included in duplicate in each plate.

\section{Statistical analysis}

Affymetrix ${ }^{\circ}$ Tiling Analysis Software (TAS) was used for analysis and quality control of the GeneChip Tiling Arrays. TAS analyzed feature intensity data stored in GeneChip ${ }^{\circ}$ Operating Software (GCOS), output cel files and produced signals and p-values for each genomic position interrogated. Affymetrix Power Tools Software 1.15.1 was used to convert cel files to text files. The methylation regions of fetus group and mother control group were compared by using Modle-based Analysis of Tiling-array (MAT) calculation $(p<0.0001)$. CisGenome ver 2.0 Software (http:// www.biostat.jhsph.edu/ hji/cisgenome/) was used for annotating the gene names which were close to methylation regions. Scatter plots were constructed utilizing $\mathrm{R}$ Software Packages 3.0.1. Two sets of results (the fetus and the mohter) of clone sequencing were analyzed by Quantification tool for Methylation Analysis (QUMA) and compared by statistical software SPSS Version 13.0 using Analysis of Variance (ANOVA) method $(p<0.01)$. The statistical analysis of the RTQ-PCR results was done using $\Delta \Delta C t$ methods. Analysis of Variance (ANOVA) was also used for comparison the two sets of results of RTQ-PCR $(p<0.01)$. 
Table 2 The primers for clone sequencing

\begin{tabular}{|c|c|c|c|}
\hline Primer name & Forward primer & Reverse primer & Amplicon size (bp) \\
\hline $\mathrm{FH} 1$ & GGAGTTITTATGTATTTGGTATTT & CATACCCCCAAAAAATAAAATTTAAAATCT & 383 \\
\hline $\mathrm{FH} 2$ & ATGGGGAAGTAGATTTGGGTAT & TCACTTTAACTACCCCCAAATATTATAA & 456 \\
\hline $\mathrm{FH} 3$ & TAGGGGTGTTATGAAGGTGGTA & ATTCTATATAATCACTTCCACATTCTTAAT & 418 \\
\hline $\mathrm{FH} 4$ & AGGGTTGGGTAATATTITTATTGTTATAAT & ACAAACCAAATTACCCCCATT & 492 \\
\hline FH5 & ATGGGAGGTGGGTITGTT & AAAATCACCTACCAACCTCAATAACTA & 446 \\
\hline FH6 & GGTTITTAGATTTGGATGTGATTTAGG & CCCCCCCATAAATAAAACCTT & 470 \\
\hline $\mathrm{FH7}$ & GTGGAGATAGTAGTGAGTAGAGA & AATCCCATATAAACCCAAACCT & 484 \\
\hline $\mathrm{FH} 8$ & TITITITGTAGTTAAGGGTITITGTAT & СТСТTСTAAAACATCCACCTTACA & 391 \\
\hline FH9 & TGAGAAATTTAAGGAGTGTGTGT & TACCCCCATCTATCCTATACTCT & 452 \\
\hline FL1 & GGGAGGAAGGAGTTGGTAGGTTITAT & ACTACCCAAATCTCTCACTITACAATAAC & 357 \\
\hline $\mathrm{FL} 2$ & GTITTAGTAAGTTIITGGGGAGAGG & AACAACTAATTTCACACCATATCTTAT & 349 \\
\hline FL3 & TGGGAAGTATGTGGAAGTGGA & CACCCCCCATTTTAAAAACAACAATCTAT & 290 \\
\hline FL4 & GGAAATGTGTTAAGGTAAGAGGTTATAAG & СCAAAACTTСТACCCCTAAAAAT & 452 \\
\hline FL5 & TाTGTTAAGAATAATAAGAGAGGGTAAGT & ATCTATAAATCTIIITTCCAAACTCAC & 481 \\
\hline FL6 & GGGTTITTGTTTAATTGTGTATTGGAG & ACCTAACCAAACCCCATACT & 388 \\
\hline FL7 & GGATTATTAGTTGTATAATTATGGAGATT & ACССССТСТСТАСТAСТAATATAA & 378 \\
\hline FL8 & AAGGGGATTITITTGGAAAGTAT & CATCTCAAACTCTCACCATCATAAATA & 489 \\
\hline FL9 & GTGTITAGTAATAGGTAGTITGGAAAATT & СТTACTTACAATTCCAATACCTATAATCAC & 435 \\
\hline FL10 & TGGTATTAGTGGGAGTTTAATAGATG & AACTCAAATAAACCCACATACACTATAAT & 413 \\
\hline FL11 & TGGATTGATATAGGGAAAAAAAAGGAGAA & САСТСССАAАТСТСТАСТАACСТCTA & 465 \\
\hline FL12 & GTGGGTTTATTAGGTTGTGAGTA & СТTAAACTCСТСТTССССАACAC & 350 \\
\hline
\end{tabular}

$\mathrm{FH}$ indicates fetus hypermethylation DNA markers and FL indicates fetus hypomethylation DNA markers.

\section{Results and discussion}

DNA Methylation is a crucial epigenetic modification involved in embryonic development, transcription, chromation structure, $\mathrm{X}$ chromosome inactivation, gene imprinting, chromosome stability and occurrence of different kinds of tumors [10-15]. In recent years, researchers have conducted extensive studies on the mechanism of DNA methylation and its role in embryonic development using different biological models, such as human and mouse cell lines, gene knockout mice, zebra fish and so on [6,7,16-18]. These studies all show that DNA methylation is important for regulating temporal and spatial expression of genes for controlling cell fate and differentiation. In some other studies, DNA methylation has been demonstrated to be required for vertebrate early embryogenesis [19-21]. Here we collect eight pairs of amniotic fluid and maternal blood samples for selecting the hypermethylation and hypomethylation DNA markers. The fetus and mother DNA samples are all amplified by using the PowerPlex 16 system kit in a multiplex amplification reaction system and there is no maternal DNA in fetus amniotic fluid.

DNA methylation analysis of the 8 pairs amniotic fluid and maternal blood DNA samples are conducted by using GeneChip Human Tiling 2.0R Array set. In this study, from the fetus and mother groups we have got

Table 3 The primers for real-time quantitative PCR

\begin{tabular}{cllc}
\hline Primer name & Forward primer & Reverse primer & Amplicon size (bp) \\
\hline ERG & TCCCCGTGACATCTTCCAGT & AGCCTCCGCCAGGTCTTA & 140 \\
SH2D3C & GGCTAAAGGAACTGTCAGAAAATG & CGGGTTGAAGGAAGAAGTGAC & 95 \\
EML3 & CTTCAACCCTCGTGACAGCA & ATTCCCAGGAACCCCTACTC & 94 \\
TRIM71 & TCACAGCTTCATCTACCTCCA & GTACTTCATGCGGCGATTCT & 195 \\
HOXA3 & TTCCACTTCAACCGCTACCT & CTGGACCCGAGACGTAGTAAGT & 111 \\
HOXA11 & GCCCAAGGTAGCCCAATAA & GGATAGCGACCGCAAAATG & 94 \\
HOXA5 & GCGAGCCACAAATCAAGCA & & 77 \\
\hline
\end{tabular}


the values of the DNA methylation levels for thousands of methylation markers respectively. In order to get fetus methylation markers which are significant different from that of mother in DNA methylation level, we have compared the values of the DNA methylation levels of the methylation markers of fetus with that of mother by using MAT calculation $(p<0.0001)$. Scatter plots are constructed to show the results of the comparison using R Software Packages 3.0.1. Two of the Scatter plots were showed in Figure 1. As shown in Figure 1, red solid triangles which represent the DNA methylation level of fetus in this chromosomal location gathered together, blue open circles which represent the DNA methylation level of mother in this chromosomal location gathered together, and red solid triangle groups are separated from blue open circle groups. If the Scatter plots results are the same as Figure 1, we can determine that there must be significant different in DNA methylation level from that of fetus and mother. According to the above principle we select 59 fetus hypermethylation DNA markers and 56 fetus hypomethylation DNA markers which all show significant differences between fetus and
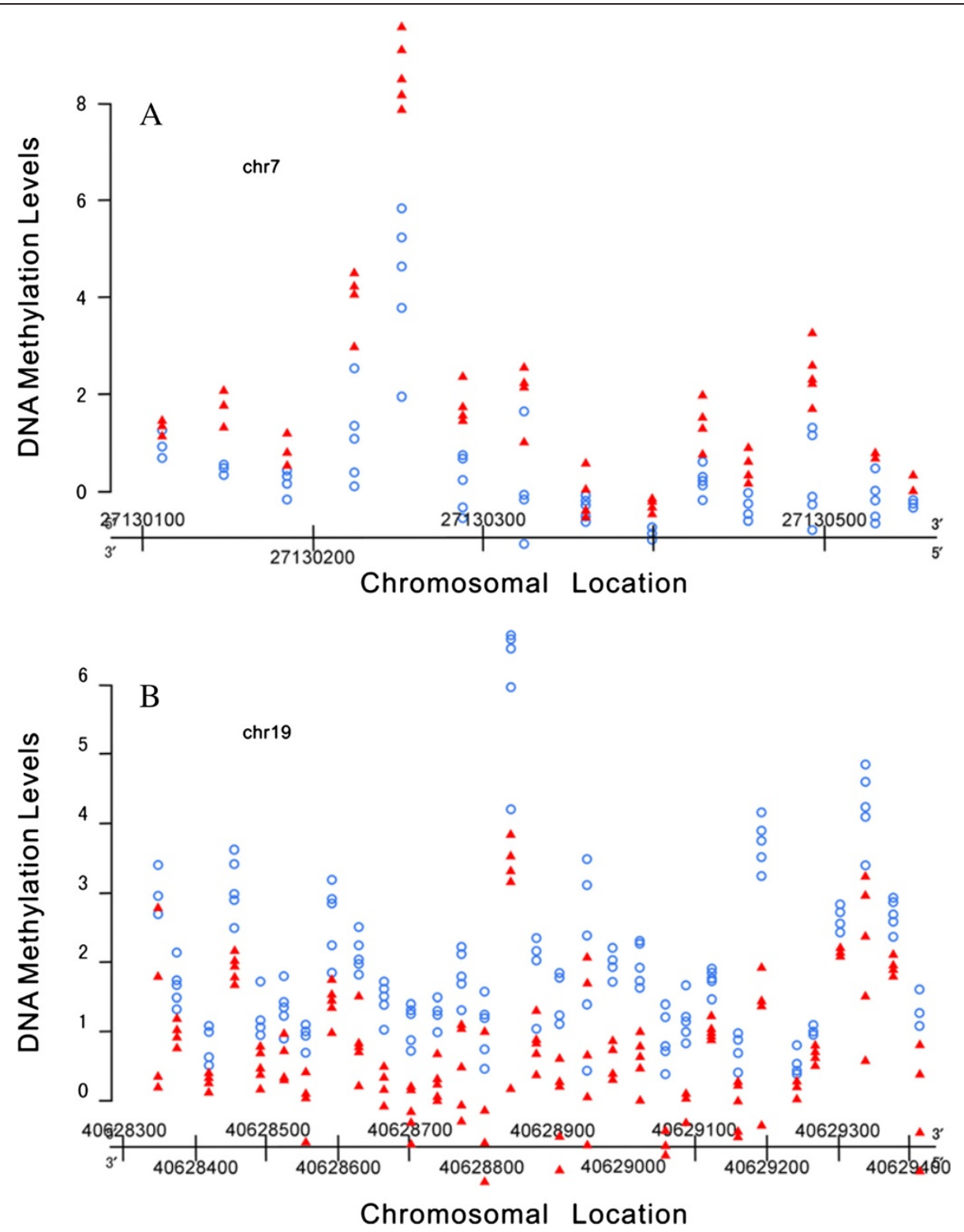

Figure 1 The scatter plots generated by using R software packages based on the methylation degree. (A) The fetus hypermethylation DNA marker (HOXA3) on chromosome 7; (B) The fetus hypomethylation DNA marker (FFAR2) on chromosome 19. *Red solid triangle represent the DNA methylation level of fetus in this chromosomal location; Blue open circle represent the DNA methylation level of mother in this chromosomal location. 
mothers. To further understand the sequence structure and function of the 59 fetus hypermethylation DNA markers and 56 fetus hypomethylation DNA markers, we check their associated genes where these markers locate in (http://www.ncbi.nlm.nih.gov/). We have finally identified 9 fetus hypermethylation DNA markers and 12 fetus hypomethylation DNA markers and their associated genes according to their function (showed in Table 4).

To test and verify the 21 selected methylation DNA markers by microarray analysis method in a wholegenome wide, we used clone sequencing strategy. One of the clone sequencing results was shown in Figure 2. The results of clone sequencing were analyzed by Quantification tool for Methylation Analysis (QUMA) and compared by statistical software SPSS Version 13.0 using Analysis of Variance (ANOVA) method $(p<0.01)$. According to the results of ANOVA, we finally selected 7 methylation DNA markers from the 21 according to the results of the clone sequencing. They are FH4 (Chr21:38,791,600-38,792,000), FH7 (Chr9:129,579,800129,580,000), FL1 (Chr7:27,130,100-27,130,600), FL2 (Chr11: 62,127,350-62,127,700), FL3 (Chr3:32,835,500-32,835,800), FL4 (Chr7:27,185,300-27,185,650) and FL7 (Chr7:27,148,050$27,148,400)$.
If these 7 genes are really regulated by specific methylation status in the fetus, the mRNA expression of ERG and $\mathrm{SH} 2 \mathrm{D} 3 \mathrm{C}$ should be lower in the amniotic fluid, whereas those of EML3, TRIM71, HOXA3, HOXA5, and HOXA11 are higher in the amniotic fluid than in the maternal peripheral blood cells. To verify the function of the 7 genes, we did the real-time quantitative PCR (RTQ-PCR) comparison between amniotic fluid samples and maternal peripheral blood cells on these 7 genes. The results of the RTQ-PCR were consistent with the clone sequencing results. However, Analysis of Variance (ANOVA) showed that only SH2D3C was reduced by $0.47 \pm 0.33$ folds $(p<0.01)$ in the amniotic fluid, and EML3, TRIM71, HOXA3, and HOXA5 were enhanced by $1.31 \pm 0.72,2.57 \pm 1.37,13.07 \pm 9.45$ and $2.38 \pm 2.69$ folds $(p<0.01)$ respectively in the amniotic fluid than in the maternal peripheral blood cells. In order to clarify whether the differences between mother and fetus were due to fetus gender differences, the experimental data were grouped according to fetus gender. The Analysis of Variance (ANOVA) results showed that there were no significant differences between male and female fetuses in methylation status. So we conclude that the differences in methylation status between mother and fetus have nothing to do with gender differences in our study.

Table 4 The information of the 9 fetus hypermethylation DNA markers (FH) and 12 fetus hypomethylation DNA markers (FL)

\begin{tabular}{|c|c|c|}
\hline Marker ID & Chromosomal locition & Associated gene \\
\hline $\mathrm{FH} 1$ & ChrM:1-542 & Mitochondrial DNA D-loop \\
\hline $\mathrm{FH} 2$ & ChrM:16,025-16,571 & Mitochondrial DNA D-loop \\
\hline $\mathrm{FH} 3$ & Chr19:40,628,281-40,629,300 & Free fatty acid receptor 2 (FFAR2) \\
\hline $\mathrm{FH} 4$ & Chr21:38,791,600-38,792,000 & Erythroblastosis virus E26 oncogene onmcogene homolog (ERG) \\
\hline $\mathrm{FH} 5$ & Chr7:2,411,800-2,412,100 & Carbohydrate (chondroitin 4) Sulfotransferase 12 (CHST12) \\
\hline FH6 & Chr12:6,528,400-6,528,750 & Intermediate filament family orphan 1 (IFFO1) \\
\hline $\mathrm{FH7}$ & Chr9:129,579,800-129,580,000 & $\mathrm{SH} 2$ domain containing $3 \mathrm{C}(\mathrm{SH} 2 \mathrm{D} 3 \mathrm{C})$ \\
\hline $\mathrm{FH} 8$ & Chr17:36,717,500-36,717,900 & Keratin associated protein 16-1 (KRTAP16-1) \\
\hline FH9 & Chr19:1,019,900-1,020,200 & Histocompatibility (minor) HA-1 (HMHA1) \\
\hline FL1 & Chr7:27,130,100-27,130,600 & Homeobox A3 (HOXA3) \\
\hline FL2 & Chr11:62127350-62127700 & Echinoderm microtubule associated protein like 3 (EML3) \\
\hline FL3 & Chr3:32,835,500-32,835,800 & Tripartite motif containing 71, E3 ubiquitin protein ligase (TRIM71) \\
\hline FL4 & Chr7:27,185,300-27,185,650 & Homo sapiens homeobox A11 (HOXA11) \\
\hline FL5 & Chr6:10,664,250-10,664,600 & Homo sapiens glucosaminyl (N-acetyl) transferase 2, I-branching enzyme (GCNT2) \\
\hline FL6 & Chr7:27,113,100-27,113,300 & Homo sapiens homeobox A2 (HOXA2) \\
\hline FL7 & Chr7:27,148,050-27,148,400 & Homeobox A5 (HOXA5) \\
\hline FL8 & Chr19:12,997,300-12,997,450 & Nuclear factor I/X (NFIX) (CCAAT-binding transcription factor) \\
\hline FL9 & Chr8:116,753,900-116,754,200 & Homo sapiens trichorhinophalangeal syndrome I (TRPS1) \\
\hline FL10 & Chr5:95,321,600-95,321,800 & Elongation factor, RNA polymerase II, 2 (ELL2) \\
\hline FL11 & Chr7:32,213,400-32,213,600 & Phosphodiesterase 1C, calmodulin-dependent (PDE1C) \\
\hline FL12 & Chr8:82,066,300-82,066,500 & Phosphoprotein associated with glycosphingolipid microdomains 1 (PAG1) \\
\hline
\end{tabular}




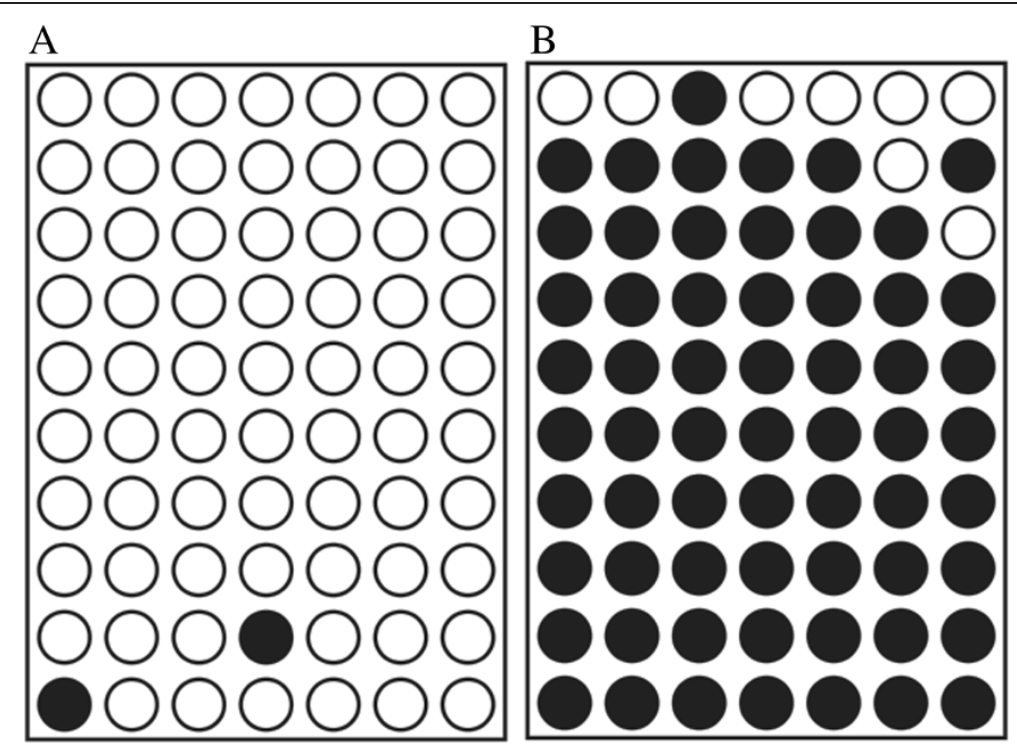

Figure 2 The clone sequencing result of methylation DNA marker located on chromosome 21:38791600-38792000. The DNA Marker is a fetus hypermethylation DNA marker and related with Erythroblastosis virus E26 oncogene onmcogene homolog (ERG) gene. (A) The clone sequencing result of the mother, (B) The clone sequencing result of the fetus * $X$ axis represents different methylation sites; $Y$ axis represents different clones. *black circle represent methylation sites; white circle represent unmethylated sites.

Marker FH7 was associated with SH2D3C gene which encoded an adaptor protein and was a member of cytoplasmic protein family involved in cell migration. Until now, Research on the function of SH2D3C gene was still very rare. Marker FL2 was associated with EML3 gene which was a nuclear microtubule-binding protein required for the correct alignment of chromosomes in metaphase [22]. Marker FL3 was associated with TRIM71 gene which cooperated with microRNAs to repress Cdkn1a expression and promote embryonic stem cell proliferation [23,24]. HOX genes called homeobox genes encoded the class of transcription factors were found in clusters A, B, C, and D on four separate chromosomes. The expression of these genes was spatially and temporally regulated during embryonic development. Marker FL1 was associated with HOXA3 gene which was a member of HOX gene family and was part of the A cluster on chromosome 7. It encoded a DNAbinding transcription factor which may regulate gene expression, morphogenesis and differentiation. Marker FL7 was associated with HOXA5 gene which also encoded the class of transcription factors. As HOXA3, the expression of this gene was spatially and temporally regulated during embryonic development. Methylation of this gene may result in the loss of its expression. Since the encoded protein up-regulates the tumor suppressor p53, this protein may play an important role in tumorigenesis. The previous studies showed HOX genes were involved in stem cell differentiation [25]. High-density association study of the HOX gene for volumetric BMD at the femoral neck and lumbar spine among older men was conducted and proved that HOXA gene regions were associated with both femoral neck and lumbar spine BMD [26]. However, HOX genes has not been given enough attention that they can regulate gene expression, morphogenesis, and differentiation and were involved in the regulation of uterine development and required for female fertility.

\section{Conclusions}

In this study, we found 1 fetus hypermethylation DNA markers and 4 fetus hypomethylation DNA markers which all associated with the critical genes for fetus growth and development. Our results may provide valuable information for future research of fetus growth and development, and even can give some inspiration of the studies of the pathological pregnancy, such as Unexplained Recurrent Spontaneous Abortion (URSA) and early pregnant failure which generally occur at about 20 weeks in the embryonic development [27].

\section{Competing interests}

The authors declare that they have no competing interests.

\section{Authors' contributions}

HDW and QFH carried out the molecular genetic studies, DNA methylation analysis experiments, and drafted the manuscript. SXL and BFZ participated in the design of the study and drafted the manuscript. QNG, TL and DW extracted DNA and carried out the sequence alignment and Clone sequencing experiments. HX and KY carried out the RTQ-PCR. XPZ and LG performed the statistical analysis. $Y C$ and $\mathrm{MH}$ participated in samples recruitments. All authors read and approved the final manuscript. 


\section{Acknowledgments}

This project was supported by the National Natural Science Foundation of China (NSFC, No. 81170581) and the National Natural Science Foundation of China (NSFC, No. 81373248).

\section{Author details}

${ }^{1}$ Medical Genetic Institute of Henan Province, Henan Provincial People's Hospital, People's Hospital of Zhengzhou University, Zhengzhou 450003, PR China. ${ }^{2}$ School of Medicine, Xi'an Jiaotong University, Xi'an 710061, PR China. ${ }^{3}$ Armed police Guangxi Corps Hospital, Nanning 530003, PR China.

Received: 25 December 2013 Accepted: 10 April 2014

Published: 15 April 2014

\section{References}

1. Geiman TM, Muegge K: DNA methylation in early development. Mol Reprod Dev 2010, 77(2):105-113.

2. Takahashi T, Matsuda Y, Yamashita S, Hattori N, Kushima R, Lee YC, Igaki H, Tachimori Y, Nagino M, Ushijima T: Estimation of the fraction of cancer cells in a tumor DNA sample using DNA methylation. PLOS One 2013, 8(12):e82302.

3. Pinto $R$, De Summa S, Pilato B, Tommasi S: DNA Methylation and miRNAs regulation in hereditary breast cancer. Curr Mol Med 2013. In press.

4. Jones PA, Takai D: The role of DNA methylation in mammalian epigenetics. Science 2001, 293(5532):1068-1070.

5. Xiang H, Zhu J, Chen Q, Dai F, Li X, Li M, Zhang H, Zhang G, Li D, Dong Y, Zhao L, Lin Y, Cheng D, Yu J, Sun J, Zhou X, Ma K, He Y, Zhao Y, Guo S, Ye M, Guo G, Li Y, Li R, Zhang X, Ma L, Kristiansen K, Guo Q, Jiang J, Beck S, et al: Single base-resolution methylome of the silkworm reveals a sparse epigenomic map. Nat Biotechnol 2010, 28(5):516-520.

6. Sen GL, Reuter JA, Webster DE, Zhu L, Khavari PA: DNMT1 maintains progenitor function in self-renewing somatic tissue. Nature 2010, 463(7280):563-567.

7. Trowbridge JJ, Snow JW, Kim J, Orkin SH: DNA methyltransferase 1 is essential for and uniquely regulates hematopoietic stem and progenitor cells. Cell Stem Cell 2009, 5(4):442-449.

8. Gu TP, Guo F, Yang H, Wu HP, Xu GF, Liu W, Xie ZG, Shi L, He X, Jin SG, lqbal K, Shi YG, Deng Z, Szabó PE, Pfeifer GP, Li J, Xu GL: The role of Tet3 DNA dioxygenase in epigenetic reprogramming by oocytes. Nature 2011, 477(7366):606-610

9. Borgel J, Guibert S, Li Y, Chiba H, Schübeler D, Sasaki H, Forné T, Weber M: Targets and dynamics of promoter DNA methylation during early mouse development. Nat Genet 2010, 42(12):1093-1100.

10. Zhou F, Tao G, Chen X, Xie W, Liu M, Cao X: Methylation of OPCML promoter in ovarian cancer tissues predicts poor patient survival. Clin Chem Lab Med 2013, 11:1-8.

11. Suzuki M, Shigematsu H, Shames DS, Sunaga N, Takahashi T, Shivapurkar N, lizasa T, Frenkel EP, Minna JD, Fujisawa T, Gazdar AF: DNA methylationassociated inactivation of TGF $\beta$-related genes, DRM/Gremlin, RUNX3, and HPP1 in human cancers. Br J Cancer 2013, 109(12):3132.

12. Verma M, Rogers S, Divi RL, Scully SD, Nelson S, Su LJ, Ross S, Pilch S, Winn DM, Khoury MJ: Epigenetic research in cancer epidemiology: trends, opportunities, and challenges. Cancer Epidemiol Biomarkers Prev 2013 In press.

13. Wang X, Douglas KC, Vandeberg JL, Clark AG, Samollow PB: Chromosomewide profiling of $\mathrm{X}$-chromosome inactivation and epigenetic states in fetal brain and placenta of the opossum, Monodelphis domestica. Genome Res 2013. In press.

14. Bala Tannan N, Brahmachary M, Garg P, Borel C, Alnefaie R, Watson CT, Thomas NS, Sharp AJ: DNA methylation profiling in X;autosome translocations supports a role for $\mathrm{L} 1$ repeats in the spread of $X$ chromosome inactivation. Hum Mol Genet 2013. In press.

15. Girardot M, Feil R, Llères D: Epigenetic deregulation of genomic imprinting in humans: causal mechanisms and clinical implications. Epigenomics 2013, 5(6):715-728

16. Hodges E, Molaro A, Dos Santos CO, Thekkat P, Song Q, Uren PJ, Park J, Butler J, Rafii S, McCombie WR, Smith AD, Hannon GJ: Directional DNA methylation changes and complex intermediate states accompany lineage specificity in the adult hematopoietic compartment. Mol Cell 2011, 44(1):17-28.
17. Fang X, Corrales J, Thornton C, Scheffler BE, Willett KL: Global and gene specific DNA methylation changes during zebrafish development. Comp Biochem Physiol B Biochem Mol Biol 2013, 166(1):99-108.

18. Rai K, Nadauld LD, Chidester S, Manos EJ, James SR, Karpf AR, Cairns BR, Jones DA: Zebra fish Dnmt1 and Suv39h1 regulate organ-specific terminal differentiation during development. Mol Cell Biol 2006, 26(19):7077-7085.

19. Bulut HE, Ozdemir O, Başimoglu-Koca Y, Korkmaz M, Atalay A: Effects of a DNA demethylating agent-5-azacytidine-on testicular morphology during mouse embryo development. Okajimas Folia Anat Jpn 1999 76(1):47-53.

20. Snyder MD, Pryor JH, Peoples MD, Williamson GL, Golding MC, Westhusin ME, Long CR: 122 suppression of epigenetic modifiers alters the bovine embryonic developmental program during in vitro culture. Reprod Fertil Dev 2013, 26(1):175.

21. Kraushaar DC, Zhao K: The epigenomics of embryonic stem cell differentiation. Int J Bio/ Sci 2013, 9(10):1134-1144.

22. Tegha-Dunghu J, Neumann B, Reber S, Krause R, Erfle H, Walter T, Held M, Rogers P, Hupfeld K, Ruppert T, Ellenberg J, Gruss OJ: EML3 is a nuclear microtubule-binding protein required for the correct alignment of chromosomes in metaphase. J Cell Sci 2008, 121(Pt 10):1718-1726.

23. Lin YC, Hsieh LC, Kuo MW, Yu J, Kuo HH, Lo WL, Lin RJ, Yu AL, Li WH: Human TRIM71 and its nematode homologue are targets of let-7 microRNA and its zebrafish orthologue is essential for development. Mol Biol Evol 2007, 24(11):2525-2534.

24. Chang HM, Martinez NJ, Thornton JE, Hagan JP, Nguyen KD, Gregory RI: Trim71 cooperates with microRNAs to repress Cdkn1a expression and promote embryonic stem cell proliferation. Nat Commun 2012, 3:923.

25. Chung N, Jee BK, Chae SW, Jeon YW, Lee KH, Rha HK: HOX gene analysis of endothelial cell differentiation in human bone marrow-derived mesenchymal stem cells. Mol Biol Rep 2009, 36(2):227-235.

26. Yerges LM, Klei L, Cauley JA, Roeder K, Kammerer CM, Moffett SP, Ensrud KE, Nestlerode CS, Marshall LM, Hoffman AR, Lewis C, Lang TF, Barrett-Connor E, Ferrell RE, Orwoll ES, Zmuda JM, MrOS Research Group: High-density association study of 383 candidate genes for volumetric BMD at the femoral neck and lumbar spine among older men. J Bone Miner Res 2009, 24(12):2039-2049.

27. Lambrot R, Xu C, Saint-Phar S, Chountalos G, Cohen T, Paquet M, Suderman $M$, Hallett $M$, Kimmins S: Low paternal dietary folate alters the mouse sperm epigenome and is associated with negative pregnancy outcomes. Nat Commun 2013, 4:2889.

doi:10.1186/1755-8794-7-18

Cite this article as: Wang et al.: DNA methylation study of fetus genome through a genome-wide analysis. BMC Medical Genomics 2014 7:18.

\section{Submit your next manuscript to BioMed Central and take full advantage of:}

- Convenient online submission

- Thorough peer review

- No space constraints or color figure charges

- Immediate publication on acceptance

- Inclusion in PubMed, CAS, Scopus and Google Scholar

- Research which is freely available for redistribution 